\title{
ANALISIS PROFITABILITAS PENGEMBANGAN USAHA TERNAK ITIK PETELUR DI KECAMATAN BANYUBIRU KABUPATEN SEMARANG JAWA TENGAH
}

\author{
Aditya Dwi Mulyono', Wulan Sumekar², Dwi Sunarti² \\ ${ }^{1}$ Sarjana Membangun Desa-Wirausahawan Pendamping Kabupaten Semarang. \\ Dinas Pertanian, Perikanan dan Pangan, Kabupaten Semarang. \\ Jl. Letjen Suprapto No.7 Ungaran. \\ ${ }^{2}$ Fakultas Peternakan dan Pertanian, Universitas Diponegoro, Semarang. \\ Kompl. drh. R. Soejono Koesoemowardojo, Tembalang, Semarang. \\ Email: d.mulyono25@gmail.com
}

\begin{abstract}
INTISARI
Penelitian ini bertujuan untuk mengetahui profitabilitas usaha ternak itik di Kecamatan Banyubiru, Kabupaten Semarang, Provinsi Jawa Tengah. Metode yang digunakan adalah metode survei dengan 59 responden peternak itik petelur. Hasil penelitian menunjukkan bahwa peternak di Kecamatan Banyubiru rata-rata memelihara sebanyak 116 ekor itik. Pendapatan rata-rata perbulan yang diperoleh sebesar Rp 1.917.808,00. Hasil analisis profitabilitas menunjukkan Net Profit Margin sebesar 42,74\%, ROI sebesar 26,54\%, dan Rasio Laba-Biaya sebesar 74,63\%.
\end{abstract}

Kata kunci : Itik, Laba, Profitabilitas

\begin{abstract}
The purpose of this study is to know the profitability of laying ducks farm in Banyubiru Subdistrict, Semarang Regency, Central Java Province. This research were collected using 59 respondents was conducted survey method. The results showed that the average ducks farmers in District Banyubiru maintained 116 ducks. Average monthly income of farmers IDR 1.917.808,00. Profitability laying ducks farming business is shown by Net Profit Margin value of 42.74\%, ROI of 26.54\%, and CostProfit Ratio of $74.63 \%$.
\end{abstract}

Key word: Duck, Profit, Profitability

\section{PENDAHULUAN}

\section{Latar Belakang}

Permintaan produk hewani yang semakin meningkat, seiring dengan kesadaran masyarakat akan kebutuhan gizi dan meningkatnya pendapatan per kapita, menjadikan peternakan menjadi salah satu sub sektor pertanian yang memiliki peluang usaha menjanjikan untuk dijalankan. Salah satu usaha peternakan yang memiliki potensi dan peluang besar untuk dijalankan adalah ternak unggas lokal. Permintaan terhadap produk unggas lokal terutama telur itik semakin meningkat dari tahun ke tahun dikarenakan telur merupakan salah satu produk hewani yang paling murah dan mudah untuk didapatkan oleh masyarakat. Data yang dipublikasikan dalam Statistik Peternakan Jawa Tengah (2014) menyatakan bahwa terjadi peningkatan produksi telur itik dari tahun 2011 hingga 2013 sebesar 2.760 ton telur itik dengan ratio kenaikan sebesar 2,13\%. Tingginya produksi dipengaruhi oleh 
permintaan pasar yang semakin meningkat sehingga peternak harus menambah populasi itiknya.

Kecamatan Banyubiru telah banyak dikenal oleh masyarakat sebagai sentra ternak itik di Kabupaten Semarang. Satrio et al. (2015) menyatakan bahwa Kecamatan Banyubiru memiliki daya dukung wilayah yang tinggi dalam pengembangan usaha ternak itik. Berdasarkan data Badan Pusat Statistik Kabupaten Semarang (2015), populasi itik di Kecamatan Banyubiru sebanyak 8.500 ekor dengan produksi telur sebanyak 305.814 butir. Kajian ekonomi yang mendalam tentang pendapatan dan profitabilitas usaha ternak itik merupakan cerminan dari untung atau tidaknya suatu usaha. Rasyaf (2002) berpendapat bahwa besarnya pendapatan dari usaha ternak itik merupakan salah satu pengukur yang penting untuk mengetahui seberapa jauh usaha peternakan itik mencapai keberhasilan. Manfaat dari penelitian ini yaitu dapat dijadikan acuan dalam pengembangan usaha ternak itik petelur dan dapat dijadikan referensi pengambilan kebijakan untuk pemerintah daerah.

\section{Tujuan Penelitian}

Mengetahui profitabilitas usaha ternak itik yang dicerminkan dengan Net Profit Margin (NPM), Return on Investment (ROI) dan rasio laba-biaya yang diterima oleh peternak itik di Kecamatan Banyubiru, Kabupaten Semarang, Jawa Tengah.

\section{MATERI DAN METODE}

\section{Penentuan Lokasi}

Penentuan lokasi penelitian dilakukan dengan metode purposive sampling dengan pertimbangan bahwa lokasi ini telah dikenal sebagai sentra ternak itik petelur di Kabupaten Semarang. Sebanyak tiga desa dalam kecamatan Banyubiru dipilih sebagai lokasi pengambilan responden.

\section{Pengumpulan Data}

Penelitian dilakukan dengan metode survei, yaitu penelitian yang mengambil sampel dari satu populasi dan menggunakan kuesioner sebagai alat pengumpulan data yang pokok. Data primer yang meliputi identitas responden, zooteknis pengelolaan ternak itik, penerimaan usaha ternak itik, pengeluaran usaha ternak itik, dan investasi yang ditanamkan diperoleh dari hasil observasi dan wawancara terhadap responden dengan bantuan kuesioner. Data sekunder berkaitan dengan usaha ternak itik diperoleh dari observasi dan catatan pada instansi terkait.

\section{Analisis Data}

\section{Total biaya (Total Cost)}

Total biaya sama dengan biaya tetap ditambahkan biaya variabel (Soekartawi, 2003). Rumus yang digunakan untuk menghitung biaya total adalah: 


\section{$\mathrm{TC}=\mathrm{TFC}+\mathrm{TVC}$}

\section{Keterangan :}

$\mathrm{TC}=$ Total Cost atau biaya yang dikeluarkan peternak (Rp/bulan)

$\mathrm{FC}=$ Fixed Cost atau total biaya tetap $(\mathrm{Rp})$

$\mathrm{VC}=$ Variable Cost atau total biaya variabel(Rp)

\section{Penerimaan (Revenue)}

Penerimaan adalah penerimaan produksi dari hasil penjualan outputnya (Boediono, 2002), secara matematis dapat ditulis sebagai berikut :

\section{$\mathrm{TR}=\mathrm{Q} \times \mathrm{P}$}

\section{Keterangan :}

$\mathrm{TR}=$ Total Revenue atau penerimaan yang diterima peternak (Rp/bulan)

$\mathrm{Q}=$ Quantity atau jumlah (butir)

$\mathrm{P}$ = Price atau harga (Rp)

\section{Pendapatan}

Pendapatan adalah perbedaan antara hasil penjualan yang diperoleh dengan biaya total yang dikeluarkan (Sukirno, 2003).

$\pi=\mathrm{TR}-\mathrm{TC}$

Keterangan :

$\pi=$ Pendapatan (Rp)

$\mathrm{TR}=$ Total Revenue atau total penerimaan(Rp)

$\mathrm{TC}=$ Total Cost atau biaya yang dikeluarkan peternak (Rp/bulan)

\section{Net Profit Margin (NPM)}

NPM adalah kemampuan peternak itik petelur untuk menghasilkan keuntungan dibandingkan dengan penjualan yang dicapai (Bastian dan Suhardjono, 2006).

$$
N P M=\frac{\text { Laba Bersih }}{\text { Penjualan }} \times 100 \%
$$

\section{Return on Investmen (ROI)}

ROI adalah kemampuan suatu usaha untuk menghasilkan keuntungan yang akan digunakan untuk menutup investasi yang dikeluarkan (Kasmir, 2012).

$$
\text { ROI }=\frac{\text { Laba Bersih }}{\text { Investasi }} \times 100 \%
$$

\section{Rasio laba biaya}

Rasio laba biaya adalah perbandingan antara laba bersih yang dihasilkan dengan jumlah biaya produksi yang dikeluarkan (Kasmir, 2012).

$$
\text { Rasio } \mathrm{L}=\frac{\text { Laba Bersih }}{\text { Biaya Produksi }} \times 100 \%
$$

\section{HASIL DAN PEMBAHASAN}

\section{Potensi Kecamatan Banyubiru}

Kecamatan Banyubiru merupakan salah satu kecamatan di wilayah Kabupaten Semarang Provinsi Jawa Tengah. Kecamatan Banyubiru mempunyai curah hujan rata-rata 23,16 mm/hari dan $4.268 \mathrm{~mm} /$ tahun dengan jumlah hari hujan 140 hari/tahun. Suhu harian berkisar antara $23^{\circ} \mathrm{C}$ sampai $32^{\circ} \mathrm{C}$ dengan kelembaban $72 \%$ sampai $84 \%$. Kecamatan Banyubiru berada diketinggian 850 meter dari permukaan laut. Kecamatan ini sebagian besar tanahnya digunakan untuk daerah pertanian yang hampir seluruhnya ditanami padi. Dilihat dari potensi wilayahnya, Kecamatan Banyubiru sangat mendukung untuk 
pengembangan usaha tani-ternak, karena memiliki lahan yang cukup potensial untuk mendukung pengembangan ternak itik.

Potensi yang mendukung perkembangan usaha ternak khususnya itik adalah adanya rawa yang berada di Kecamatan Banyubiru. Luas Rawa pening seluruhnya adalah 6.488,558 Ha. Bagi peternak keberadaan rawa sangatlah penting karena dapat menambah sumber bahan pakan untuk itik. Ketersediaan pakan tambahan di wilayah Rawa Pening ini mampu untuk dijadikan acuan bagi peternak pada saat naiknya harga pakan disaat musimmusim tertentu.

Keberadaan rawa disekitar Kecamatan Banyubiru juga berfungsi untuk mengaliri sawah yang berada di masing-masing desa sekitar rawa, sawah ini pada musim panen telah selesai banyak digunakan oleh peternak untuk menggembalakan itiknya selain di rawa. Sistem penggembalaan itik semacam ini dapat membantu peternak untuk dapat menghemat pakan yang diberikan. Selain itu penggembalaan yang dilakukan peternak juga dapat menambah nutrisi pakan karena itik dapat memakan hewan-hewan air seperti ikan, keong atau juga bekicot. Sistem budidaya pemeliharaan ternak itik di Kecamatan Banyubiru kebanyakan ialah dengan sistem pemeliharaan semi intensif, dimana sebagian aktivitas itik dilakukan didalam dan diluar kandang. Hal ini dikarenakan Kecamatan Banyubiru ialah daerah persawahan, sehingga pada siang hari itik dilepaskan untuk mencari pakan sendiri dan ini biasanya dilakukan peternak pada saat selesai musim panen padi.

\section{Profil Responden Peternak Itik Petelur}

Jumlah responden terpilih adalah 59 peternak dengan rata-rata kepemilikan itik sebanyak 116 ekor yang berasal dari 3 desa, yaitu Desa Banyubiru, Desa Ngrapah, dan Desa Tegaron. Desa Banyubiru terdiri dari 34 peternak dengan jumlah populasi ternak sebanyak 3.983 ekor, Desa Ngrapah terdiri dari 15 peternak dengan jumlah populasi sebanyak 1.490 ekor, dan Desa Tegaron terdiri dari 10 peternak dengan jumlah populasi ternak 1.366 ekor. Responden peternak itik di Kecamatan Banyubiru memiliki latar belakang pendidikan, umur, mata pencaharian dan pengalaman beternak yang berbeda-beda. Identitas responden peternak itik di Kecamatan Banyubiru pada Tabel 1.

\section{Profil Usaha Peternakan Itik Petelur}

Bibit itik petelur yang digunakan oleh peternak adalah bibit itik yang siap berproduksi yaitu rata-rata 5 bulan, karena bibit itik umur 6 bulan tersebut sudah banyak yang bertelur. Peternak di Kecamatan Banyubiru banyak yang memelihara jenis itik pengging, dengan itik pengging merupakan itik lokal yang berasal dari Desa Krasak Kagokan, Kecamatan Gatak, Kabupaten Sukoharjo, itik ini merupakan jenis itik petelur unggul yang mempunyai produksi telur 110 sampai 130 butir/tahun. Harga bibit itik petelur antara Rp40.000,00 sampai Rp60.000,00/ekor untuk itik yang berumur 5 bulan. Pakan yang digunakan pada itik di Kecamatan Banyubiru umumnya adalah bekatul, aking, dan konsentrat (Tabel 2). Pemberian pakan 
diberikan 2 kali sehari yaitu pada pagi hari pukul 07.00 WIB dan sore hari pada pukul 16.00 WIB. Pemberian pakan ini dicampur menggunakan air sehingga menjadi pakan halus yang berbentuk basah sehingga memudahkan itik untuk makan mengingat itik merupakan unggas air yang memiliki keistimewaan pada paruhnya. Hal ini sesuai dengan pendapat Suharno dan Amri (2004) menambahkan bahwa pemberian pakan pada itik dapat dilakukan dengan beberapa cara, salah satunya yaitu pemberian pakan halus dalam bentuk basah wet mash feeding. Selain pemberian pakan itik mendapatkan pakan tambahan dari sawah dan daerah rawa, karena sistem pemeliharaan yang digunakan adalah semi intensif penggembalaan ini bertujuan agar itik mendapat pakan tambahan berupa siput, ikan ataupun bekicot. Hal ini sesuai penelitian Ketaren (2004) yang melaporkan bahwa pemberian keong mas (Pomacea caniculata) sebagai pengganti tepung ikan dalam pakan itik memberikan pengaruh terhadap konsumsi pakan itik, dengan jumlah pemberian $20 \%$ keong mas segar tanpa kerabang dari seluruh jumlah pakan dapat menungkatkan konsumsi pakan itik sebagai pengganti tepung ikan. Pemberian air minum diberikan secara ad libitum dengan cara menyediakan ember berukuran sedang yang setara dengan 52 liter air maupun pembuatan kolam kecil.

Tabel 1. Identitas Responden Peternak Itik di Kecamatan Banyubiru

\begin{tabular}{|c|c|c|c|}
\hline No. & Identitas & $\begin{array}{l}\text { Jumlah } \\
\text { (Orang) }\end{array}$ & Persentase (\%) \\
\hline \multirow[t]{4}{*}{1.} & Umur & & \\
\hline & 20-64 tahun & 52 & 88,14 \\
\hline & $>64$ tahun & 7 & 11,86 \\
\hline & Jumlah & 59 & 100,00 \\
\hline \multirow[t]{7}{*}{2.} & Tingkat Pendidikan & & \\
\hline & Tamat SD & 22 & 37,29 \\
\hline & Tamat SLTP & 19 & 32,20 \\
\hline & Tamat SLTA & 14 & 27,73 \\
\hline & Perguruan Tinggi & 1 & 1,69 \\
\hline & Tidak Sekolah & 3 & 5,08 \\
\hline & Jumlah & 59 & 100,00 \\
\hline \multirow[t]{8}{*}{3.} & Mata Pencaharian & & \\
\hline & Bertani dan buruh tani & 21 & 35,59 \\
\hline & Beternak & 32 & 54,24 \\
\hline & Pedagang & 2 & 3,39 \\
\hline & Satpam & 1 & 1,69 \\
\hline & Buruh Bangunan & 1 & 1,69 \\
\hline & Guru/PNS & 2 & 3,39 \\
\hline & Jumlah & 59 & 100,00 \\
\hline \multirow[t]{5}{*}{4.} & Pengalaman Beternak & & \\
\hline & 1-5 tahun & 2 & 3,30 \\
\hline & 6-10 tahun & 10 & 16,95 \\
\hline & $>10$ tahun & 47 & 79,66 \\
\hline & Jumlah & 59 & 100,00 \\
\hline
\end{tabular}


Tipe kandang yang digunakan oleh peternak adalah tipe kandang ren dan koloni postal. Lantai kandang umumnya dari tanah yang diberi alas yaitu jerami padi. Hal ini sesuai dengan pendapat Suharno dan Amri
(2004), bahwa pada kandang ren dan koloni postal sebaiknya lantai kandang perlu diberi alas seperti sekam, jerami, atau bahan lain yang empuk, tidak mudah padat, hangat, dan dapat mencegah telur pecah.

Tabel 2. Jenis Pakan dan Harga Itik di Kecamatan Banyubiru

\begin{tabular}{cccc}
\hline No & Pakan & $\begin{array}{c}\text { Rataan Pemberian } \\
(\mathrm{kg} / \text { hari })\end{array}$ & $\begin{array}{c}\text { Harga } \\
(\mathrm{Rp} / \mathrm{hari})\end{array}$ \\
\hline 1 & Bekatul & 5 & $3.000,00$ \\
2 & Aking & 4 & $4.000,00$ \\
3 & Konsentrat & 1 & $8.500,00$ \\
\hline
\end{tabular}

\section{Produktivitas dan Pemasaran Produk}

Produksi telur itik per hari memiliki rataan 84 butir, jumlah kepemilikan ternak itik berkisar 70 hingga 300 ekor dengan rata-rata kepemilikan itik 116 ekor, rataan Duck Day Production di Kecamatan Banyubiru adalah 76,69\% dengan konversi ransum 2,96. Pengambilan telur biasanya dilakukan pada pagi hari pada pukul 06.00 WIB, harga jual telur dengan harga rata-rata Rp1.800,00/butir. Penjualan telur itik tidak mengalami kesulitan karena dilakukan melalui pedagang pengumpul yang langsung mengambil telur setiap hari kepada para peternak. Rasuli et al. (2007), mengatakan bahwa pemasaran telur itik paling banyak dilakukan menggunakan pedagang perantara biasanya para pedagang perantara ini langsung mendatangi peternakpeternak itik untuk dijual langsung ke konsumen.

\section{Biaya Produksi}

Biaya produksi merupakan gabungan antara biaya tetap dan biaya variabel yang dikeluarkan untuk satu kegiatan produksi. Biaya paling besar pada peternak itik petelur yaitu biaya pakan sebanyak Rp1.616.123,00 atau sebesar 62,8\%. Menurut Murtidjo (2003) biaya pakan memegang persentase paling tinggi dalam usaha peternakan yaitu antara $60 \%$ hingga $70 \%$ dari total biaya produksi. Biaya produksi lain seperti tenaga kerja, obat dan vaksin serta listrik yang masuk dalam perhitungan komponen biaya, merupakan komponen biaya yang diperhitungkan dari usaha ternak itik petelur (Tabel 3).

\section{Penerimaan}

Penerimaan yang diperoleh dari peternak itik petelur adalah penjualan telur setiap hari yang dijual dalam bentuk telur mentah. Suharno dan Amri (2004) menyatakan bahwa telur merupakan hasil utama dari sebuah peternakan itik petelur, hasil sampingannya berupa kotoran yang dapat digunakan sebagai pupuk atau itik culling yang dapat dijual sebagai itik pedaging. Produksi rata-rata telur itik sebanyak 2.493 butir per bulan (83 butir per hari) dengan persentase Duck Day Production sebanyak $76,69 \%$. Rataan penerimaan setiap peternak dari usaha ternak itik petelur per bulan sebesar Rp4.487.492,00. 
Tabel 3. Komponen Biaya Produksi

\begin{tabular}{lrr}
\hline \multicolumn{1}{c}{ Jenis } & Jumlah (Rp) & Persentase (\%) \\
\hline Rataan Biaya Tetap & & \\
Penyusutan & $96.063,00$ & 4,00 \\
Biaya Tenaga Kerja & $847.881,00$ & 33,00 \\
Jumlah & $943.945,00$ & 37,00 \\
Rataan Biaya Tidak Tetap & & \\
$\quad$ Pakan & $1.616 .123,00$ & 62,80 \\
Biaya Obat dan Vitamin & $3.627,00$ & 0,14 \\
Listrik & $1.932,00$ & 0,08 \\
Jerami & $7.684,00$ & 0,30 \\
Jumlah & $1.625 .738,00$ & 63,00 \\
\hline Total & $2.569 .683,00$ & 100,00 \\
\hline
\end{tabular}

\section{Pendapatan}

Pendapatan yang diperoleh peternak adalah selisih dari penerimaan yang dikurangi dengan total biaya produksi, diukur dengan satuan rupiah. Pendapatan rata-rata yang diterima per bulan yang diterima peternak adalah Rp1.917.808,00 dengan rata- rata jumlah itik sebanyak 116 ekor, pendapatan tersebut dihitung dari total penerimaan Rp4.487.492,00 dikurangi dengan total biaya produksi Rp2.569.683,00. Berdasarkan perhitungan, pendapatan yang diterima peternak itik bernilai positif (untung). Hal ini disebabkan produksi telur yang masih tinggi diatas, sehingga dapat menutup harga pakan yang relatif tinggi (Tabel 4).

Tabel 4 Rata-rata Laba (Rp) Peternak/Bulan

\begin{tabular}{lll}
\hline No & \multicolumn{1}{c}{ Uraian } & Jumlah \\
\hline 1 & Rata-rata Penerimaan & $4.487 .492,00$ \\
2 & Rata-rata Biaya Produksi & $2.569 .683,00$ \\
\hline \multicolumn{2}{l}{ Laba } & $1.917 .808,00$ \\
\hline
\end{tabular}

Nilai Rata-rata NPM, ROI dan Rasio Laba Biaya Usaha Ternak Itik

Untuk mengetahui kemampuan usaha ternak itik dalam memperoleh laba, digunakan perhitungan Net Profit Margin (NPM), Return on Investment (ROI), dan Rasio Laba-Biaya. Besarnya nilai GPM, ROI, dan Rasio Laba-Biaya usaha ternak itik dapat dilihat pada Tabel 5.

Angka ROI 26,54\% berarti bahwa setiap Rp1.000.000,00 modal yang diinvestasikan akan menghasilkan keuntungan sebesar
Rp265.400,00. Nilai perhitungan ROI lebih tinggi dibandingkan suku bunga deposito bank yang berlaku yaitu pada kisaran 5,5\% yang berarti bahwa usaha ternak itik dapat dijalankan.

Nilai NPM 42,74\% memiliki arti bahwa usaha ternak itik petelur mampu menghasilkan keuntungan sebesar 42,74\% atau setiap penjualan $\mathrm{Rp} 1.000 .000,00 \mathrm{mampu}$ menghasilkan keuntungan sebesar Rp427.400,00. 
Nilai Rasio laba-biaya 74,63\% berarti bahwa setiap biaya yang dikeluarkan menghasilkan laba sebesar 74,63\%, atau jika mengeluarkan Rp1.000.000,00 untuk biaya produksi akan menghasilkan laba sebesar Rp746.300,00 (Tabel 5).

Berdasarkan acuan suku bunga deposito bank yang berlaku antara 5,5\% hingga 6,5\%, angka indikator profitabilitas usaha ternak itik di Kecamatan Banyubiru menunjukkan kemampuan menghasilkan keuntungan yang lebih tinggi dibandingkan bunga bank.

Oleh karena itu usaha ternak itik petelur layak untuk dijalankan atau bersifat menguntungkan sebagai usaha peternakan rakyat guna memperbaiki tingkat pendapatan masyarakat pedesaan dan menopang perekonomian daerah dari sektor peternakan.

Tabel 5 Nilai NPM, ROI dan Rasio Laba Biaya Usaha Ternak Itik Petelur di Kecamatan Banyubiru Kabupaten Semarang.

\begin{tabular}{llc}
\hline No & \multicolumn{1}{c}{ Indikator Profitabilitas } & Rataan Nilai (\%) \\
\hline 1 & NPM & 42,74 \\
2 & ROI & 26,54 \\
3 & Rasio Laba-Biaya & 74,63 \\
\hline
\end{tabular}

\section{KESIMPULAN DAN SARAN}

\section{Kesimpulan}

Berdasarkan hasil penelitian yang telah dilakukan dapat disimpulkan bahwa usaha ternak itik petelur di Kecamatan Banyubiru, Kabupaten Semarang mampu menghasilkan laba Rp1.917.808,00/bulan dengan rataan kepemilikan itik sebanyak 116 ekor, dengan nilai NPM sebesar 42,74\%, ROI 26,54\%, dan Rasio laba-biaya 74,63\% yang persentase nilai keuntungannya lebih tinggi dibandingkan dengan suku bunga deposito bank.

\section{Saran}

Melihat potensi wilayah di Kecamatan Banyubiru berada diantara daerah segitiga emas (Kota Semarang, Kota Solo dan Daerah Istimewa Yogyakarta) dan potensi ekonomi usaha yang profitable, memungkinkan peternakan itik petelur untuk dijadikan usaha pokok serta mampu dikembangkaan untuk menciptakan lapangan kerja di pedesaan.

\section{DAFTAR PUSTAKA}

Badan Pusat Statistik Kabupaten Semarang. 2015. https://semarangkab.bps.go.id/link TabelStatis/view/id/95. Diakses 25 Januari 2015.

Bastian, Idra., Suhardjono. 2006. Akuntansi Perbankan, Edisi Pertama. Salemba Empat. Jakarta.

Boediono. 2002. Ekonomi Mikro. Badan Penerbit Fakultas Ekonomi. Yogyakarta.

Dinas Peternakan Propinsi Jawa Tengah. 2014. Buku Statistik Peternakan Tahun 2014. Dinas Peternakan dan Kesehatan Hewan Provinsi Jawa Tengah. Ungaran.

Kasmir. 2012. Analisis Laporan Keuangan. Raja Grafindo Persada. Jakarta.

Ketaren, P. P. 2004. Keong mas (Pomacea caniculata) sebagai pengganti tepung ikan pakan itik jantan. Prosiding Seminar Nasional 2006. Universitas Diponegoro. Semarang.

Murtidjo. A.M. 2003. Mengelola Itik. Kanisius. Yogyakarta.

Rasuli, N., M.A. Saade., dan K. Ekasari. 2007. Analisis margin pemasaran telur itik di Kelurahan Borongloe, Kecamatan 
Bontomarannu, Kabupaten Gowa. Jurnal Agrisistem. 5(3):36-43.

Rasyaf, M. 2002. Beternak Itik Komersial. Edisi ke- 6. Kanisius. Yogyakarta.

Satrio, Y. W., S.I. Santoso, dan A. Setiadi. 2015. Analisis pengembangan usaha ternak itik di Kecamatan Banyubiru Kabupaten Semarang. Animal Agriculture Journal. 4(2): 256-259.

Soekartawi. 2003. Agribisnis Teori dan Aplikasi. PT. Raja Grafindo Persada. Jakarta.

Suharno, B. dan K, Amri. 2004. Beternak Itik Secara Intensif. Panebar Swadaya. Jakarta.

Sukirno, S. 2003. Pengantar Teori Mikroekonomi. Edisi Ketiga. Raja Grafindo Persada. Jakarta. 